DOI: https://doi.org/10.32839/2304-5809/2021-11-99-80

УДК 339.17

Гринюк Н.А., Намчук М.O.

Київський національний торговельно-економічний університет

\title{
СУТНІСТЬ ТА ЕФЕКТИВНІСТЬ ПОСЕРЕДНИЦЬКОЇ ДІЯЛЬНОСТІ В МІЖНАРОДНОМУ БІЗНЕСІ
}

\begin{abstract}
Анотація. У статті досліджено теоретичні-методологічні аспекти формування механізму посередницької діяльності у міжнародному бізнесі. Проаналізовано сутність, роль та особливості міжнародної посередницької діяльності, принципи діяльності міжнародних посередників, коло послуг, які вони пропонують. Залежно від основних функцій, визначено види торговельного посередництва. Проаналізовані переваги та недоліки залучення міжнародних посередників для підвищення ефективності діяльності підприемства. Також обірунтовано актуальні проблеми посередництва у міжнародному бізнесі. Виявлено сучасні тенденції розвитку міжнародних посередницьких операцій, перспективу подальшого розвитку цього напряму торговельної діяльності, а також з'ясовано основні напрями підвищення ефективності посередництва в контексті посилення міжнародної конкурентоспроможності України.
\end{abstract}

Ключові слова: торговельне посередництво, агент-представник, брокер, комісійний агент, дистриб'ютор, міжнародний бізнес.

Hrynyuk Nataliya, Namchuk Maria Kyiv National University of Trade and Economics

\section{ESSENCE AND EFFICIENCY OF INTERMEDIARY TRADE IN INTERNATIONAL BUSINESS}

Summary. The article investigates the theoretical and methodological aspects of forming the mechanism of intermediary activity in international business. The essence, role and features of global intermediary trade, principles of trade intermediary, range of services they offer are analyzed. The role of intermediaries in today's marketplace is continually emphasized in foreign and local literature. However, despite the significant scientific research of these scientists, the problem of intermediary trade is not fully covered, so it needs further investigation. Moreover, in highly developed areas of the world economy, it continues to grow, primarily due to the unique ability of intermediaries to reduce the time it takes to deliver value. One of the reasons for this is that the successful sale of goods in a competitive environment is becoming more intense and includes many components: the range and quality of goods, price, advertising, constant availability in shopping centers and others. Moreover, the manufacturer of a product often tries to be represented in markets in one country and around the world. The article determines that the time factor is the key competitive advantage of intermediary traders. Depending on the main functions, the types of trade intermediation are defined. The advantages and disadvantages of involving international intermediaries to increase the efficiency of the enterprise are analyzed. Furthermore, the current problems of intermediaries in international business are also substantiated. There is no doubt that without attraction, Ukrainian enterprises can't cooperate with intermediary traders to provide acceptable conditions for the sale of products and services in foreign markets and therefore achieve the minimum required level of competitiveness. Finally, the modern tendencies of development of global intermediary operations, prospects of further development of this direction of trade activity are revealed, and the basic principles of increasing intermediary trade efficiency in strengthening international competitiveness strengthening of Ukraine are found out. Based on the material above, there is a conclusion that the problems of the theory and methodology of supply chain management, including a variety of intermediary traders, are relevant. This article aims to substantiate the intermediary activity features in international business and the prospect of further development of this trade direction.

Keywords: intermediary trade, trade agent, broker, commission agent, distributor, international business.

$\Pi^{2}$ остановка проблеми. Дослідження особливостей діяльності міжнародних посередників є досить актуальною на сьогодні. адже внаслідок розширення масштабів міжнародної торгівлі та інвестиційного співробітництва, роль посереднищьких операцій зростає. Однак, залишаються невиявленими сучасні тенденщї розвитку посереднищьких операцій у міжнародному бізнесі, а також основні напрями вдосконалення ефрективності їх діяльності в контексті підвищення міжнародної конкурентоспроможності України.

Аналіз останніх досліджень і публікацій. Питання едрективності посереднищької діяльності у міжнародному бізнесі знайшли відображення у працях таких вітчизняних та зарубіжних науковців, як Т.С. Рожкова, В.В. Апопій, Я.І. Функ, С.В. Ніколюкін, Г.Ф. Шершеневич, А.Б. Борисов, О.М. Вінник, С.М. Пермінов, Д. Папа, Л. Еліот та ін. Проте, незважаючи на значні наукові дослідження названих учених проблема посередництва висвітлена не в повній мірі, отже потребуе подальших досліджень.

Виділення невирішених раніше частин загальної проблеми. У сучасних умовах, коли у світі спостерігається велика кількість інтегращійних процесів, послуги посередників стають дедалі актуальнішими та необхідними. Однією з причин цього $є$ те, що процес успішного продажу товару в умовах конкуренції стає все більш насиченим і включає безліч складових: асортимент і якість товару, його ціну, рекламу, постійну наявність у торговельних центрах та ін. Часто виробник тіеї чи іншої продукції намагається бути представленим на ринках не лише на ринку одніеї країни, а й всього світу. Тому зростає і роль посередників, які беруть на себе цю відповідальність. Проте вивчення наукової літератури свідчить про недостатне обгрунту- 
вання џього явища у сучасному середовищі. Тому слід детальніше розглянути посередництво як багатоаспектний соціально-економічний феномен.

Мета статті. Головною метою даної роботи $€$ обгрунтування особливостей посередницької діяльності у міжнародному бізнесі та перспектива подальшого розвитку цього напряму торговельної діяльності.

Виклад основного матеріалу. Під міжнародними торговельно-посередницькими операщіями розуміють ті, що пов'язані 3 купівлеюпродажем товарів, виконуються за дорученням експортера-виробника незалежним від нього торговельним посередником на основі укладеної між ними угоди. Міжнародне торговельне посередництво може включати послуги з пошуку закордонного контрагента, підготовки та здійснення угоди, кредитування сторін і надання гарантій оплати товару покупцем, здійснення транспортно-експедиторських операцій і страхування товарів при транспортуванні, митне одормлення вантажу, проведення рекламних та інших заходів щодо просування товарів на іноземні ринки, здійснення технічного обслуговування та ін.

З точки зору методу здійснення зовнішньоторговельних операцій їх можна поділити на прямі та опосередковані. Перші припускають безпосередню взаємодію між продавцем (виробником) товару і кінцевим споживачем або спеціалізованим гуртовиком (магазином). Другі - взаємодію продавця з покупцем через третю особу, яка виступає торговельним посередником.

Перевага прямих операцій полягає в економічності та гнучкості їх відносин між продавцем і покупцем, які можуть швидко узгоджувати окремі питання, що потребують уточнень, вирішувати розбіжності, задовольняти претензії один одного. На основі прямих зв'язків здійснюються постачання обладнання, встановлення, налагодження та експлуатація якого вимагають додаткових послуг з боку виробника, постачання на основі договорів, які передбачають заміну застарілої продукції на її нові модифрікації та ін. Водночас безпосередня реалізація багатьох товарів на іноземному ринку ускладнюе їх збут необхідністю вивчення ринку, у зв'язку з цим виникають додаткові витрати.

Торговельне посередництво охоплюе широке коло послуг:

- пошук іноземного контрагента;

- підготовка та укладання договорів;

- кредитування сторін і надання гарантій оплати товару покупцем;

- здійснення транспортно-експедиторських операцій;

- страхування товарів при транспортуванні;

- виконання митних формальностей;

- проведення рекламних та інших заходів щодо просування товарів на зовнішні ринки;

- здійснення технічного обслуговування та інші послуги.

Торговельний посередник несе певні витрати при здійсненні своєї діяльності, основними з яких $є$

- заробітна плата управлінського персоналу та працівників сервісних служб;

- амортизаційні відрахування на будівлі, спорудження, канцелярське устаткування, машини; - витрати на підтримку будівель, споруджень, на зв'язок, рекламу, представницькі витрати;

- митні та транспортно-експедиторські витрати;
- витрати на підтримку субагентської мережі;

- податки та збори [6].

Торговельне посередництво є переважно комерційною діяльністю, хоча найбільші з посередницьких фрірм виконують і виробничі операції, необхідні для ефрективної реалізації товарів.

Залучення торговельного посередника дозволяє збільшити прибуток шляхом:

- підвищення ефрективності продажу товару та прискорення обороту капіталу;

- продажу товарів на зовнішньому ринку, оскільки посередники, перебуваючи поруч із кінцевими споживачами, оперативніше реагують на будь-які зміни попиту;

- скорочення періодів зберігання та передпродажного обслуговування;

- зменшення витрат на розподіл на одиницю продукції.

В умовах товарного ринку посередники - це суб'єкти незалежного і специфрічного бізнесу, які здійснюють свою торговельну діяльність на основі наступних принципів:

- тотожність сторін (рівноправні партнерські взаємовідносини посередника 3 виробниками та споживачами продукції);

- підприемливість (зацікавленість у реалізації резервів);

- оперативність (своєчасність виконання завдань постачально-збутової діяльності);

- обслуговування контрагентів (діяльність 3 надання послуг іншим агентам);

- комерціалізація (активність, що стосується прибутків);

- договірні взаємовідносини [3].

Залежно від фрункцій, виконуваних посередниками, можна вирізнити такі види торговельно-посередницької діяльності:

- торговельно-посередницька діяльність із перепродажу товарів;

- торговельно-посередницька діяльність зі створення умов для здійснення актів купівліпродажу, організації товарообігу [1].

На сьогодні у розвинених країнах залучення міжнародних посередників у бізнесі має тенденцію сталого зростання. Так, за підрахунками експертів, у США фрункціонують близько 20 типів посередницьких структур, а з урахуванням товарної спеціалізації їх кількість перевищуе кілька тисяч. При цьому в США на незалежних посередників припадає 52\% загального обсягу продажу продукції, тоді як на частку гуртових фрілій промислових компаній - лише 40\%. У Японії діють понад 120000 посередницьких структур, частка яких припадає майже на $60 \%$ обсягу продажів продукції виробничо-технічного призначення [2].

Значення посередницьких компаній у сучасному міжнародному бізнесі важко переоцінити. Посередники, від імені гуртових і роздрібних підприемств, є найважливішим механізмом збуту на глобальному ринку. Багаторічний досвід закордонних компаній доводить, що кінцевий ефект від використання посередників $€$ значно вищим, ніж виробництво власної збутової мережі. Особливо вагомою є роль посередників у продажу товарів масового попиту за кордоном, оскільки в цьому випадку близькість до споживачів і швидкість пристосування до потреб, що стрімко змінюються, набуває найбільшого значення. Як приклад можна навести збутові струк- 
тури найбільших транснаціональних корпорацій - General Motors, Mitsubishi, Nestlé, IBM, які здійснюють збут своїх товарів через величезну мережу посередницьких компаній у всьому світі.

Великі компанії використовують посередників переважно для діяльності на важкодоступних ринках і за умови реалізації другорядних видів продукції. Своєю чергою, малий та середній бізнес часто не може обійтися без посередників за всіма напрямами своєї діяльності, що пов'язано 3 нестачею внутрішніх матеріальних, трудових та інформаційних ресурсів. При цьому у деяких сфрерах міжнародного бізнесу посередники вже стали незамінним елементом: наприклад, у біржовій торгівлі та в міжнародних тендерах компанії не обійтися без використання посередницьких структур.

Посилаючись на іноземного посередника, українські підприемства керуються відповідними нормами міжнародного приватного права, які застосовуються до експортно-імпортних операцій українських підприемств.

В основному посередники, що діють за мандатними та комісійними контрактами, іменовані як "агенти", а контракти, підписані з посередниками "агентські угоди".

Широке застосування у договірній практиці розробили окремі фірми, а також міжнародні урядові та неурядові організації. Наприклад, Міжнародна торгова палата склала Настанови щодо укладання агентських контрактів.

Посередників у міжнародному бізнесі можна класифікувати залежно від обсягу наданих їм повноважень та від їх місця на ринку. Права та обов'язки посередників визначаються в контрактах 3 їхніми умовами. Таким чином, основна умова, яка лежить в основі поділу подібних контрактів на типи, полягає в наступному: чи має посередник право підписувати операції 3 третіми особами, чиїм коштом і від імені кого він може це зробити.

Тому посередників можна поділити на чотири основні групи:

I. посередники, які не мають права укладати угоду 3 третіми сторонами (агенти-представники, брокери);

II. посередники, які підписують операції з третіми особами від свого імені, але коштом довірителя (комісіонери, одержувачі);

III. посередники, що підписують операції з третіми особами від імені та коштом довірителя (агенти-мандати, торгові агенти);

IV. посередники, що підписують операції 3 третіми сторонами від свого імені та власним коштом (продавці, дистриб'ютори, дилери).

\section{I. Агенти-представники}

Агент-представник захищае інтереси лише довірителя згідно з узгодженою номенклатурою товарів. Він не отримуе ліцензію на підписання будь-яких контрактів на товари від свого імені. До обов'язків агента-представника входять:

- проводити маркетингові дослідження та інформувати довірителя про тенденщії ринку;

- надавати довірителю інформацію про технічні вимоги до товарів та ціни;

- інформувати довірителя про запити споживачів, про майбутні замовлення;

- створювати сприятливе враження про довірителя та його товари в ділових колах та проводити рекламу;
- сприяти укладанню та реалізації контрактів;

- організувати ділові контакти 3 імпортерами товарів, державними та іншими організаціями, від яких залежать рішення щодо розміщення замовлень.

На роль агентів-представників залучаються солідні фірми або фізичні особи, що займають досить високе становище в ділових колах. Якщо за допомогою такого агента можна укласти договір - йому виплачуеться компенсація у розмірі 2-5\%. При великих сумах операцій цієї суми буде достатньо, і вона перевищить реальні витрати агента. Однак довіритель у майбутньому вже може мати операції з цим покупем без участі агента-представника.

\section{II. Брокери}

Брокерські операщії здійснюються профресійними посередниками - брокерами, які працюють суворо за певними товарами чи операціями.

Брокери - це особи, які здійснюють операції з продажу та придбання товару, але юридично не виступають ні як продавець, ні як покупець. Їх завдання - знайти покупця для продавця, а продавця для покупця та сприяти підписанню договору між ними. Доречним прикладом є брокери в Англії, що займаються торгівлею деревини, адже майже всі операції з торгівлі деревиною в цій країні здійснюються через посередників.

Роботу брокера схематично можна описати наступним чином:

1. Експортер звертається до брокера з проханням знайти покупщя на даний товар у будь-якій країні.

2. Брокер звертається до імпортера з пропозицією придбати даний товар у експортера.

3. За згодою сторін брокер зустрічається з колегами;

- контрагенти підписують контракт;

- експортер доставляе товар.

Брокер отримуе невелику компенсацію за посередництво i, як правило, від тієї сторони, яка до нього звернеться першою. Якщо звернення є одноразовим, то підписувати угоду нема потреби. Проте, якщо відносини мають довгостроковий характер вони оформлюються договором. Брокери торгують, як правило, великими партіями та мають значні витрати, тому ставки на їх послуги не такі високі. Великі брокерські компанії співпрацюють з банками в кредитуванні покупця, іноді виступають в ролі кредиторів, а також можуть взяти на себе гарантію для покупщя, що відповідно, підвищує ставку комісіі.

\section{III. Комісійні агенти}

Сторонами в комісійних операціях є консигнант та комісіонер. Консигнант своїм коштом доручає комісіонеру здійснити операцію купівлі-продажу. Для третього контрагента комісіонером буде сторона договору купівлі-продажу, а саме - продавець.

3 одержувачем комісіонер будуе відносини на основі договору комісії. У контракті на комісію зазвичай $є$ такі застереження:

- максимальні ціни при експорті та при імпорті;

- умови постачання товару;

- обмеження технічних та якісних характеристик товару;

- відповідальність одержувачів перед комісіонерами та комісіонерів перед одержувачами;

- порядок сплати комісійних.

Розмір комісії повинен компенсувати витрати комісіонера на здійснення торгових операщій і забезпечити йому прибуток. Звичайний розмір комісійних (при суто комісійних операціях у світовій практиці) - 1,5-3,5\% від угоди [5]. 
Другий вид комісійних операцій може бути застосований у тому випадку, якщо вантажоодержувач вимагає від комісіонера щось для продажу. Між одержувачем та комісіонером встановлюеться так званий контракт "del credere", в якому комісіонер бере на себе відповідальність за платоспроможність покупщів і компенсуе одержувачу всі витрати, якщо покупець виявляється неплатоспроможним. Комісіонер може отримати прибуток у вигляді різниці між цінами придбання товару у вантажоодержувача та реалізації покупцеві - ця сума і складе комісія комісіонера. Другий варіант для комісіонера - це коли комісія встановлюеться договором у вигляді відсотків від суми операції, але компенсація у цьому випадку буде вищою.

\section{IV. Дистриб'ютори}

Дистриб'ютори займаються продажем товарів від свого імені та своїм коштом. Вони несуть усі ризики, пов'язані з пошкодженням або втратою товару, а також 3 неплатоспроможністю покупщів.

Угоди про дистриб'юторські агенції цікаві принципалу, оскільки дають можливість вийти на нові ринки та забезпечити рекламу своїх товарів на цих ринках протягом декількох років. Вони складаються з фірм, що мають власну маркетингову мережу або засоби для її створення, супроводжуються договорами купівлі-продажу при доставленні товару, дають гарантію, на відміну від консигнаційних контрактів, отримання оплати за товар відразу після постачання товару (якщо тільки товари не доставляються в кредит), виключають ризики втрат або пошкодження товару на території іншої країни оскільки, отримуючи товар, дистриб'ютор стає його власником.

Агентська угода з дистриб'ютором, як правило, складається на тривалий термін (2-5 років) 3 подальшим продовженням за угодою сторін. Такі угоди, в основному, складаються з продажу технічних, сировинних та споживчих товарів.

Уклавши агентську угоду, в якій визначені загальні основи взаємовідносин сторін, вони укладають договори купівлі-продажу на постачання товару, за яким агент повинен отримати товари комітента, а потім передати його кінцевому споживачу. Продаж товарів - остання операція у списку обов'язків агента, перш за все він повинен організувати систему реклами та продажу, передпродажу та обслуговування протягом гарантійного періоду.

При постійних обсягах реалізації агент, якого в цьому випадку називатимуть генеральним агентом, організуе маркетингову мережу, яка складається з субагентів, які працюють у певних регіонах, і дилерів, що обслуговують окремі населені пункти. Компенсація агента розраховуеться як різниця між ціною придбання товару у комітента та його перепродажем [2].

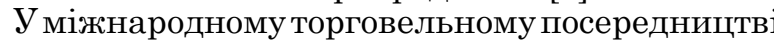
можна виділити чотири основні форми: просте посередництво, перепродаж, дистриб'юторство і представництво.

Митне оформлення товарів, яке здійснюеться дистриб'юторами, здійснюеться при експорті чи імпорті залежно від умов договору купівлі-продажу.

В Україні торговельно-посередницька діяльність розвивається досить суперечливо через роздрібненість і віддаленість постачальників та покупщів, розширення зовнішньоекономічних зв'язків, ускладнення комерційних операцій, низький професійний рівень посередників, неудосконаленість нормативної бази. В той час коли у таких країнах, як Великобританія, США, Японія, Німеччина, Швеція на частку посередників приходиться до половини обороту товарів та послуг.

Варто зазначити, що існуе невизначеність в оцінці явища посередництва, його участі в економічному житті суспільства. Проте, аналізуючи роль посередництва, варто розглянути посередництво як складне, неоднозначне і багатоаспектне явище сучасного міжнародного бізнесу.

Здатність «з'еднувати» економічних суб'єктів і становить цей специфічний продукт, постачальником якого $є$ посередники. Ця роз'єднаність суб'ектів ринку може бути як тимчасовою, так і просторовою, що особливо актуально у середовищі міжнародного бізнесу.

У сучасних умовах, коли споживач досить розбірливий, а конкуренція висока, зробити продукт - ще не означає вигідно продати його. У таких умовах і з'являються посередники, які займаються просуванням та збутом товару. У міжнародному бізнесі культурні відмінності країн світу спричиняють додаткові труднощі щодо реалізації товарів. Тому виявляється величезна кількість додаткових факторів, що впливають на успішність продажів: від практики ведення ділових переговорів до ставлення споживачів до кольору упаковування та труднощів перекладу.

3 міжнародним бізнесом також безпосередньо пов'язана просторова корисність посередництва, що полягае у зниженні витрат, які виникають через просторову роз'єднаність виробництва та споживання товарів. Дійсно, посередницькі компанії мають здатність поєднання суб'єктів ринку, навіть у тому випадку, якщо вони знаходяться на різних сторонах земної кулі. В результаті у покупщів з'являється можливість знайти потрібний їм товар за найбільш вигідною ціною. Посередники здійснять продаж товару в той момент, коли він матиме попит на ринку, миттево підберуть для кліента вигідного партнера з контактної бази, створеної завчасно. Посередники гарантують підвищення ліквідності: наприклад, можливість швидкого отримання необхідних коштів реалізуеться завдяки фрінансовим посередникам, а наявність необхідних товарів над ринком забезпечують торгові посередники. Це не тільки пояснюе об'ективну необхідність існування посереднищьких структур, але також задає необхідний рівень компетентності, який повинні мати посередники для того, щоб їх послуги користуватися попитом на світовому ринку [6].

Головною цінністю залучення посередників є підвищення ефективності окремих операцій, отже, посередники повинні надавати економічним суб'єктам можливість досягти максимальної вигоди. Можна навести конкретні фрактори, які дають посередникам можливість підвищувати ефективність бізнесу своїх клієнтів. По-перше, посередники отримують вигоду для себе і своїх кліентів за допомогою економії на масштабі. Через них проходять операції не одніеї, а декількох компаній-кліентів одночасно, що дозволяе здійснювати масштабні угоди та домагатися більших знижок та економії на витратах. Наприклад, спрямовуючи кліентів на бізнес-конференцію за кордон, міжнародне PR-агентство має можливість отримати квитки на участь у заході та номери у готелі за зниженими цінами, які є недоступними для індивідуальних покупців. 
По-друге, посередники нерідко займаються спеціалізованою діяльністю, яка полягає в обробці великої кількості стандартних операцій. У міжнародному бізнесі нерідко зустрічаються ситуації, для успішного врегулювання яких потрібні специфрічні знання. Приклади такого роду можуть бути пов'язані як з міжнародними адміністративними бар'єрами, так і 3 діловою практикою ведення бізнесу за кордоном. Так, оформлення віз для ділових поїздок в такі країни, як, наприклад, США та Канада, пов'язане 3 рядом труднощів, основною 3 яких $є$ необхідність заповнення великої форми англійською мовою. Для вирішення таких проблем існуе велика кількість компаній, які спеціалізуються на офрормленні віз та підготовці документів для посольства. Загалом саме досконале знання посередниками теорії та світової практики ведення певних операцій робить їх невід'ємними учасниками міжнародних ділових відносин.

По-трете, посередники не просто володіють досвідом ведення стандартизованих операцій, вони нерідко мають унікальну інформацію. Лише у XXI ст. поступово приходить усвідомлення того, що інфрормація є найціннішим ресурсом, ключовим для ведення успішного бізнесу та, відповідно, по всім законам ринку, не безплатним. Посередник, маючи перевагу в отриманні інформащії про можливості ринку, швидко та дешево продає цю інформацію клієнтам. У міжнародному бізнесі інформація стає ключовим фрактором, що впливає на успіх діяльності фрірми.

Ефективність японських, корейських і гонконгських торгових компаній базувалася саме на об'ємі їх знань про товарні ринки. Надзвичайно вагома роль посередників в умовах, коли компанія вперше виходить зі своїм товаром за кордон або починае продаж нового товару на зовнішньому ринку. Ризики ведення закордонного бізнесу в рази перевищують звичайні бізнес-ризики, і в першу чергу це пов'язано з незрівнянно великою кількістю інформації, без знання якої продаж товару в іншій країні ніколи не зможе досягти бажаного рівня [5].

Також варто зазначити, що посередницькі компанії в міжнародному бізнесі активно застосовують нові методи та технології, постійно удосконалюючи свою діяльність. Необхідною основою їх успішного фрункціонування є постійна оптимізація операцій, покращення обслуговування клієнтів, зниження вартості послуг. У наш час багато посередників оснащені найсучаснішими засобами зв'язку, новітніми індрормащійними та управлінськими системами. Посередницькі компанї прагнуть стати більш інноваційними, а отже, слідом за власним розвитком посередники розвивають своїх клієнтів, зокрема й світову економіку загалом.

Безперечно, у використанні посередників $\epsilon$ певні недоліки, про які не можна забувати. Залучення третьої сторони несе в собі відсутність контролю над ситуацією та втрачену вигоду від безпосереднього контакту 3 продавцем. Головним недоліком ведення бізнесу через посередника, на загальну думку, є націнка на товар. Однак, зі скасуванням посередництва ціни можуть зрости ще більше через зниження едективності торгових операцій та розвитку тіньового ринку.

Висновок. Зрештою, залучення посередників має переваги та недоліки, однак, звернення суб'єктів ринку до посередників має добровільний характер, а значить, фракт використання їхніх послуг підтверджуе суспільну корисність цього виду міжнародної торговельної діяльності. Звичайно, поки що в нашій країні ще широко поширені компанії, які значно підвищують ціну на товар виробника, видаючи його за власний. Проте поява більшої кількості ефрективних управлінців на міжнародних підприємствах, поступове вдосконалення законодавчої бази, покращення загальної економічної ситуації - сприятимуть підвищенню ефрективності посередницької діяльності, яка позитивно впливатиме на інноваційний розвиток міжнародної економіки в цілому.

\section{Список літератури:}

1. Апопій В.В. Проблеми становлення торгового посередництва в Україні. Проблели підприєлництва. 2009. № 6. C. $29-31$.

2. Гриффрітс А., Уолл С. Економіка для бізнесу і менеджменту. 2007. С. 34.

3. Дунська А.Р. Торгові посередники в зовнішньоекономічній діяльності: проблеми визначення та класифікації. URL: https://ela.kpi.ua/bitstream/123456789/2953/1/18.pdf

4. Кириченко О.А. Менеджмент зовнішньоекономічної діяльності. Киӥв : Знання, 2005. $493 \mathrm{c.}$

5. Кузьмін О.Є. Управління зовнішньоекономічною діяльністю. Львів : Центр Європи, 2001. 175 с.

6. Лукашенко Є.А. Роль посередників у підвищенні ефрективності міжнародного бізнесу. URL: http://ecsocman.hse.ru/ data/2011/05/07/1267945717/53.pdf

\section{References:}

1. Apopij V. (2009) Problemi stanovlennya torgovogo poserednictva v Ukrayini [Problems of trade intermediation formation in Ukraine]. Problemi pidpriyemnictva, no. 6, pp. 29-31.

2. Griffits A., Uoll S. (2007) Ekonomika dlya biznesu i menedzhmentu [Economics for business and management].

3. Dunska A.R. Torgovi poseredniki v zovnishnoekonomichnij diyalnosti: problemi viznachennya ta klasifikaciyi [Trade intermediaries in foreign economic activity: problems of definition and classification]. Available at: https://ela.kpi.ua/bitstream/123456789/2953/1/18.pdf

4. Kirichenko O.A. (2005) Menedzhment zovnishnoekonomichnoyi diyalnosti [Management of foreign economic activity]. Kyiv: Znannya.

5. Kuzmin O.E. (2001) Upravlinnya zovnishnoekonomichnoyu diyalnistyu [Management of foreign economic activity]. Lviv: Centr Yevropi.

6. Lukashenko E.A. Rol poserednikiv u pidvishenni efektivnosti mizhnarodnogo biznesu [The role of intermediaries in improving the efficiency of international businesss]. Available at: http://ecsocman.hse.ru/data/ 2011/05/07/1267945717/53.pdf

7. Kirichenko O.A. (2005) Menedzhment zovnishnoekonomichnoyi diyalnosti [Management of foreign economic activity]. Kyiv: Znannya. 